\title{
ANTIOXIDANT AND ANTIMICROBIAL ACTIVITY OF SELECTED MEDICINAL PLANTS AGAINST HUMAN ORAL PATHOGENS
}

\author{
LAVANYA J.a, PERIYAR SELVAM S. ${ }^{\text {** }}$, JEEVITHA PRIYA M. ${ }^{a}$, PREETHI JACINTHAa, ARADANA M. ${ }^{a}$
}

aDepartment of Biotechnology, SRM University, Kattankulathur, Tamilnadu, India, bDepartment of Food Process Engineering, SRM University, Kattankulathur, Tamilnadu, India

Email: periyar.india@gmail.com

Received: 01 Apr 2016 Revised and Accepted: 22 Jul 2016

\section{ABSTRACT}

Objective: The aim of the study was focused on determining the phytochemicals, antibacterial, antiadherence, antifungal and antioxidant activities of Glycyrrhiza glabra, Matricaria chamomilla and Eclipta alba and also their mechanism of action towards human oral pathogens.

Methods: Qualitative analysis and quantitative estimation of phenols and flavonoids were performed in methanolic extracts. Antibacterial, anti adherence, antifungal assays were performed by plate assays. Antioxidant assays were done by ABTS and DPPH methods. SEM, TEM and flow cytometry analysis were executed to find out the mechanism of action of plant extract.

Results: The total phenol contents were $0.85,1.24,0.64 \mathrm{GAE} / \mathrm{g}$ and the total flavonoid contents were 356, 231.34 and 88 $\mu \mathrm{g}$ QE/mg for G. glabra, M. chamomilla and E. alba respectively.

Matricaria chamomilla possesses highest antioxidant activity (DPPH and ABTS assays) among the all extracts tested. E. alba showed a highest zone of inhibition against S. aureus $(21.6 \mathrm{~mm})$ whereas G. glabra and M. chamomilla revealed the better result of $21 \mathrm{~mm}$ and $19.8 \mathrm{~mm}$ respectively against S. mutans.

Glycyrrhiza glabra showed antifungal activity against Candida parapsilosis whereas Pseudomonas aeruginosa, Candida krusei, Candida tropicalis and Candida albicans showed resistance towards all the extracts tested. The MIC, MBC and antiadherence tests were also performed. Sorbitol assay confirmed that G. glabra has no impact on the fungal cell wall. To confirm the mode of action SEM, TEM and flow cytometric analysis were performed which showed the cell elongation and damage in cytoplasmic membrane resulting in oozing of cellular constituents.

Conclusion: This work concluded that all the plant extracts showed potent activities among the various tests. Oral care product can be developed if the active constituents responsible for the activities were analysed.

Keywords: Antiadherence, Glycyrrhiza glabra, Matricaria chamomilla, Eclipta alba, Synergism

(C) 2016 The Authors. Published by Innovare Academic Sciences Pvt Ltd. This is an open access article under the CC BY license (http://creativecommons. org/licenses/by/4. 0/) DOI: http://dx.doi.org/10.22159/ijpps.2016v8i9.11989

\section{INTRODUCTION}

Oral infections are mostly caused by the bacteria and fungi which colonize in the tooth surfaces [1,2]. The bacteria colonize along with food debris and saliva, form a sticky substance that strongly adheres to the teeth called plaque [3]. It leads to tooth decay if it is not removed on a routine basis. The microbes present in the oral cavity produces an enzyme called glycosyltransferases and forms a waterinsoluble glucan complex from sucrose which leads to the biofilm formation [4]. The overall human health is affected due to oral health problems which lead to causes systemic infections. Meanwhile, there is a close association between chronic dental infection and general health, which indicates that dental treatment, has to be taken in earlier stages of infection. One of the important examples is edentulousness (loss of teeth) which causes malnutrition in elder people; prolonged dental infection also leads to stomach ulcers, infective endocarditis and infective arthritis. A systemic infection like leukemia causes oral ulcers [5]. On the other hand, dental treatment is very painful and more expensive. Moreover the synthetic antimicrobial drug provides a temporary solution furthermore leads to various side effects to the host like vomiting, diarrhea and tooth staining. Continuous administration of synthetic antimicrobial drugs leads to drug-resistant microbes as well as alters the oral and intestinal microflora of the host [6]. The pharmacological industries produce the potential antibiotics recently with the help of researchers even though drug resistance of the bacteria also increased in recent years [7]. It is necessary to find out alternative remedies for the oral diseases. Medicinal plants are more suitable alternate drug as well as low cost with no side effects when compared to synthetic medicine. The herbal based oral care products are needed to prevent the toxicity and tooth staining caused by triclosan, cetyl pyridinum chloride, chlorhexidine and amine fluorides $[8,9]$.

Matricaria chamomilla (chamomile), Eclipta alba (false daisy) and Glycyrrhiza glabra (licorice) are the well-known traditional medicinal plants used in the treatment of various oral infections. The flowers of chamomile, leaves of false daisy and roots of licorice were selected for our study due to its various medicinal properties and based on its use in ancient traditional medicines. Chamomile is native of Europe and Western Asia which is widely used for the treatment of intestinal cramps [10]. Similarly, licorice is seen in Southern Europe and a part of Asia and used for treating various digestive problems [11]. Eclipta alba commonly known as a false daisy, coming under the family asteraceae. It has cylindrical and grayish roots. The solitary flower heads are $6-8 \mathrm{~mm}$ in diameter with white florets. The achenes are compressed and narrowly winged. It grows commonly in moist places as a weed in warm temperate to tropical areas throughout the world. It is widely distributed throughout India, China, Thailand and Brazil.

The scientific investigation and knowledge about the plant varieties and their biological application is necessary to make use of medicinal plants effectively and commercially. Hence we are focused to determine the antioral pathogenic effect of three Matricaria chamomilla (Asteraceae) and Eclipta alba (Asteraceae) against oral bacterial pathogens such as Staphylococcus aureus, Streptococcus mutans, Streptococcus mitis, Streptococcus oralis, Lactobacillus acidophilus and Pseudomonas aeruginosa and fungal pathogens such as Candida albicans, C. parapsilosis, C. krusei and C. tropicalis. The 
oral cavity of humans is highly affected due to the adherence of microbes. Hence it is essential to prevent the initial attachment of bacteria to the oral cavity. The anti-adherence of pathogenic bacteria can be evaluated by radioactive labeling of bacteria [12-15], bacterial adhesion to microtitre plate [16] and glass surfaces [17].

Free radicals are capable of oxidizing biological macromolecules like nucleic acids, proteins, lipids $[18,19]$ which can initiate many metabolic disorders like aging, coronary heart disease and cancer, etc., [20]. Consequently, our study also focused on the determination of antioxidant (DPPH and ABTS) and phytochemical (total phenol and flavonoids) effect of three traditional medicinal plants. Although there are numerous herbs available to prevent and cure dental infections, the exact mechanism of action of these herbs are yet to be identified. Hence this is a preliminary study to check the mechanism of crude extract responsible for the biological activity.

\section{MATERIALS AND METHODS}

\section{Collection of plant materials}

The E. alba was collected from Palaniyapuri and Thalavipatti in Salem district, Tamilnadu, India. Various parts M. chamomilla and $G$. glabra were procured from GTEE Botanical Pvt. Ltd, Kottivakkam, Tamilnadu, India. The plant identification was authenticated by plant taxonomist Dr. M. Kumar from Madras Christian College, Chennai, Tamilnadu, India.

\section{Chemicals and reagents}

All chemicals and reagents used during the experimentation were of analytical grade, purchased from Southern India Scientific Corporation, Chennai, India.

\section{Preparation of plant extract}

The collected plant materials were shade dried and ground to a coarse powder. The twenty grams of powdered material was weighed and extracted with methanol in a soxhlet apparatus. Extracts were concentrated by using rotary evaporator (IKA, RV 10 digital V) and used for further studies.

\section{Qualitative analysis of phytochemical studies}

The quality analysis of various phytochemicals such as steroids, saponins, terpenoids, glycosides, tannins and flavonoids was preliminary screened by previously described methods for all the plant samples [21-23].

\section{Quantitative analysis of phenols and flavonoids}

\section{Total phenolic determination}

The plant extracts were used for the determination of total phenolic by spectrophotometrically according to the Folin-Ciocalteu colorimetric method [24]. The $200 \mu \mathrm{l}$ plant extract was taken in the screw cap test tubes, and $1 \mathrm{ml}$ of Folin-Ciocalteu reagent (1:1 with water) and $1 \mathrm{ml}$ of sodium carbonate $(7.5 \%)$ was added. The tubes were vortexed and after $2 \mathrm{~h}$ incubation, the absorbance was read at $726 \mathrm{~nm}$ using a spectrophotometer (Beckman, USA). The total phenolic content was expressed as gallic acid equivalents (GAE) in $\mathrm{mg} / \mathrm{g}$ of plant extract.

\section{Total flavonoid determination}

The total flavonoid content was determined by aluminium chloride colorimetric method [25]. The $0.1 \mathrm{mg}$ of plant extract was dissolved in $1 \mathrm{ml}$ of methanol and mixed with $0.1 \mathrm{ml}$ of $10 \%$ aluminium chloride hexahydrate, $0.1 \mathrm{ml}$ of $1 \mathrm{M}$ potassium acetate and $2.8 \mathrm{ml}$ of deionized water. The absorbance was taken at $415 \mathrm{~nm}$ in spectrophotometer after $40 \mathrm{~min}$ of incubation. Quercetin was used as a standard (the concentration range: 0.005 to $0.1 \mathrm{mg} / \mathrm{ml}$ ) and the total flavonoid content was expressed as mg quercetin equivalents per gram of dry extracts.

\section{Antioxidant activity}

\section{DPPH radical scavenging activity}

Free radical scavenging was determined by DPPH radical scavenging activity [26]. The sample solutions with a series of concentrations
$(100-500 \mu \mathrm{g} / \mathrm{ml})$ were prepared for various extracts. With a 96-well microplate, $50 \mu \mathrm{l}$ of all samples were added in different wells (in triplicates). The $100 \mu \mathrm{l}$ of $0.1 \mathrm{mM}$ DPPH in methanol was then added in each well and incubated for $30 \mathrm{~min}$. The absorbance was measured at $515 \mathrm{~nm}$. The $50 \mu \mathrm{l}$ of methanol in $100 \mu \mathrm{l}$ of DPPH solution was kept as the control and $100 \mu \mathrm{l}$ of $95 \%$ methanol was kept as the blank. Ascorbic acid at various concentrations (100 to $500 \mu \mathrm{g} / \mathrm{ml}$ ) was used as a standard. Lower the absorbance of the reaction mixture indicates higher free radical scavenging activity. The capability to scavenge the DPPH radical was calculated using the following equation.

DPPH Scavenged $(\%)=[$ OD control - OD sample $/$ OD control $]$ X100

\section{ABTS free radical scavenging activity}

The free radical scavenging capacity of plant extract was determined by using ABTS radical cation decolorization assay [27]. The $7 \mathrm{mM}$ ABTS was used for the analysis. ABTS radical cation $\left(\mathrm{ABTS}^{*+}\right.$ ) was produced by reacting ABTS stock solution with $2.45 \mathrm{mM}$ potassium persulphate (final concentration) and allowing the mixture to stand in the dark room temperature for 12-16 $\mathrm{h}$ before use. The free radical was stable for more than two days when stored in the dark room temperature. For the analysis of the test samples, the ABTS*+solution was diluted with absolute ethanol to an absorbance of $0.700( \pm 0.02)$ at $734 \mathrm{~nm}$ and equilibrated at $30^{\circ} \mathrm{C}$. Reagent blank reading was taken $\left(\mathrm{A}_{0}\right)$. After addition of $2.0 \mathrm{ml}$ of diluted ABTS $^{*+}$ solution $\left[A_{734} \mathrm{~nm}=0.700 \pm 0.02\right]$ to $20 \mu \mathrm{l}$ of the test sample, the absorbance reading was taken at $30^{\circ} \mathrm{C}$ exactly 6 min after initial mixing $\left(A_{t}\right)$. Appropriate solvent blanks were run in each assay. All determinations were carried out at least three times. The percentage inhibition (PI) of absorbance at $734 \mathrm{~nm}$ was calculated using the below formula and decrease of the absorbance between $A_{0}$ and $A_{t}$.

$$
\mathrm{PI}=\left[\left(\mathrm{A}_{\mathrm{c}}(0)-\mathrm{A}_{\mathrm{A}}(\mathrm{t})\right) / \mathrm{A}_{\mathrm{C}}(0)\right] \mathrm{X} 100
$$

Where $A_{C(0)}$ is the absorbance of the control at $t=0 \mathrm{~min}$; and $A_{A(t)}$ is the absorbance of the antioxidant at $t=6 \mathrm{~min}$.

\section{Antimicrobial activity}

\section{Microbial strains}

Oral pathogenic bacteria such as Staphylococcus aureus (MTCC 7443), Streptococcus mutans (MTCC 497), Streptococcus mitis (MTCC 2695), Streptococcus oralis (MTCC 2696), Lactobacillus acidophilus (MTCC 10307) and Pseudomonas aeruginosa (MTCC 7453) fungal species such as Candida albicans (MTCC 227), Candida parapsilosis (MTCC 6510), Candida krusei (MTCC 9215) and Candida tropicalis (MTCC 184) were obtained from Microbial Type Culture Collection (MTCC), Chandigarh, India.

\section{Disc diffusion method}

The antibacterial and antifungal activity of plant extracts were determined by disc diffusion method [28]. The dried extracts were dissolved in dimethyl sulfoxide (DMSO). The strains were first grown to logarithmic phase in Mueller-Hinton broth, and the inoculums were prepared by adjusting the turbidity of bacterial suspension to 0.5 McFarland's tube with Mueller-Hinton broth [29]. The sterile discs ( $6 \mathrm{~mm}$ in diameter) were impregnated with the concentration of $100 \mu \mathrm{g} / \mathrm{ml}$ and $250 \mathrm{mg} / \mathrm{ml}$ for antibacterial and antifungal activity respectively. The extract discs were placed on Mueller-Hinton agar plates, which were previously spreaded with test strains and incubated at $37{ }^{\circ} \mathrm{C}$ for $24-48 \mathrm{~h}$. The $30 \mu \mathrm{g} / \mathrm{ml}$ of chloramphenicol, $0.5 \mathrm{mg} / \mathrm{ml}$ of fluconazole and $100 \%$ DMSO was served as positive and negative control respectively. All tests were performed in triplicate and zones of inhibition were measured after the incubation period.

Determination of minimum inhibitory concentration (MIC) and

The minimum inhibitory concentration (MIC) of extracts was determined by serial dilution method [30]. The extracts were diluted in a two-fold manner to make different concentrations. The serial dilutions of each extract were individually placed in tubes labeled 110. Tube one was filled with $2 \mathrm{ml}$ of Muller-Hinton broth including 
the extract stock solution. Only one $\mathrm{ml}$ of the stock solution in tube one was transferred to tube 2 and diluted with $1 \mathrm{ml}$ of Muller-Hinton broth. This procedure was repeated for solutions in tubes 2-10. Each tube was then filled with $1 \mathrm{ml}$ Muller-Hinton broth including microbial suspension. The resulting mixtures were incubated at $37 \pm 0.1{ }^{\circ} \mathrm{C}$ for $24-48 \mathrm{~h}$. The solvent served as negative control. Turbidity was taken as an indication of growth and the lowest concentration which remained clear was recorded as the relative minimum inhibitory concentration. This test was done in triplicates. In order to determine minimum bactericidal and fungicidal concentration (MBC/MFC), $100 \mu \mathrm{l}$ of the content of the tube without turbidity were cultured on the Muller-Hinton agar medium and incubated at $37^{\circ} \mathrm{C}$ for $24-48 \mathrm{~h}$. This test was done in triplicates.

\section{Antiadherence activity of plant extracts}

Glass surface adherence assay was performed according to the method of Barira Islam et al. (2008). [31] with slight modification. The bacteria was grown for $24 \mathrm{~h}$ at $37^{\circ} \mathrm{C}$ at an angle of $30^{\circ}$ in a glass tube with $10 \mathrm{ml}$ of Mueller-Hinton broth (MHB) with or without $5 \%$ sucrose and various concentrations of inhibitory compound. The solvent control included MHB (with or without sucrose) and equivalent amounts of DMSO, ethanol and tween-80. After incubation, planktonic cells were decanted and the attached cells were removed by $0.5 \mathrm{M} \mathrm{NaOH}$. Adherence was quantified by reading at $600 \mathrm{~nm}$.

Percentage reduction in adherence $=\left[\left(\mathrm{A}_{\text {controll }}-\left(\mathrm{A}_{\text {sample }}\right)\right] / \mathrm{A}_{\text {control }} \mathrm{X} 100\right.$

\section{Sorbitol assay}

The impact of plant extracts on fungal cell wall can be demonstrated by sorbitol assay [32]. Initially, MIC was determined using standard broth microdilution procedure describes above. Briefly, 96 well plates containing test compounds in one row and test compounds and $0.1 \mathrm{M}$ sorbitol in the next row were prepared. All the wells are then inoculated with $100 \mu \mathrm{l}$ of fungal suspension (0.5 McFarland) and incubated. The readings were taken at $2^{\text {nd }}$ and $6^{\text {th }}$ day, and the MIC was calculated.

\section{Scanning electron microscopy}

Samples for SEM observations were prepared according to the method of Figueras and Guarro method [33] with slight modifications. Cell pellets were obtained by inoculating $100 \mu \mathrm{l}$ of cells with $10 \mathrm{ml}$ Sabouraud's dextrose broth at the MIC concentration of plant extracts. It was then incubated at $37^{\circ} \mathrm{C}$ for $48 \mathrm{~h}$ at $120 \mathrm{rpm}$. The harvested cell pellets and untreated control were fixed with $3 \%$ glutaraldehyde in $0.05 \mathrm{M}$ phosphate buffer $(\mathrm{pH} 6.8)$ at $4{ }^{\circ} \mathrm{C}$ for $48 \mathrm{~h}$ and dehydrated with series of ethanol concentration $(30 \%, 50 \%, 70 \%, 95 \%)$ each for 20 min and finally with absolute alcohol for $45 \mathrm{~min}$. The sample was then dried at a critical point in liquid $\mathrm{CO}_{2}$ and mounted on standard $1 / 2$ inch Cambridge SEM stubs and coated with Gold-Palladium electroplating (60s, $1.8 \mathrm{~mA}, 2.4 \mathrm{kV}$ ) in a Polaron SEM coating system sputter coater. The samples were examined in an LEO435 VP SEM at $15 \mathrm{kV}$ to assess changes in cell morphology.

\section{Transmission electron microscopy}

Structural changes produced by test compounds towards fungal cell were evaluated using transmission electron microscopy. Briefly, 10 $\mathrm{ml}$ of Sabouraud's dextrose broth treated with sub-inhibitory concentration of plant extracts $(62.5 \mathrm{mg} / \mathrm{ml})$ was inoculated with $100 \mu$ l of cell suspension ( $0.5 \mathrm{McF}$ arland) and incubated at $37{ }^{\circ} \mathrm{C}$ for $48 \mathrm{~h}$ at $120 \mathrm{rpm}$. Control sample did not receive treatment. The obtained cell pellets were fixed with $2.5 \%$ glutaraldehyde in $0.1 \mathrm{M}$ cacodylate buffer ( $\mathrm{pH} 7.2$ ) for $24 \mathrm{~h}$ at room temperature. Post-fixation was carried out in $1 \%$ osmium tetroxide in cacodylate buffer. Samples were dehydrated in acetone and embedded in epon. Ultrathin sections were stained with $12.5 \%$ alcoholic uranyl acetate and viewed under Morgagni 268D transmission electron microscope at $80 \mathrm{kv}$. Ultrastructure of treated and untreated cultures was compared to assess the effects of compounds.

\section{Propidium iodide influx analysis}

Propidium iodide influx analysis was performed according to the method of Jaeyong et al. (2013) [34]. Candida parapsilosis cells $(2 \mathrm{x}$ $10^{6} \mathrm{Cells} / \mathrm{ml}$ ) in log phase growth were resuspended in yeast extract peptone dextrose medium. It was then incubated with plant extracts $(62.5 \mathrm{mg} / \mathrm{ml})$ for $2 \mathrm{~h}$ at $28{ }^{\circ} \mathrm{C}$ with $140 \mathrm{rpm}$. Then the cells were harvested and resuspended in PBS and then treated with propidium iodide ( $9 \mu \mathrm{M}$, final concentration) for $5 \mathrm{~min}$. Flow cytometry was performed via FACS Caliber flow cytometry.

\section{Flow cytometric analysis}

Morphological change of Candida was determined by flow cytometry. The above mentioned prepared cells were illuminated by $480 \mathrm{~nm}$ light from an argon ionic laser and forward light scatter (FSC) and side scatters (SSC) were determined.

\section{Synergism}

Microtitre plates with two-fold dilutions of G. glabra were prepared in a horizontal orientation and the second one was used to make antifungal dilutions of fluconazole in a vertical orientation. Both dilutions were made in SDB (Sabouraud's Dextrose Broth) [50 $\mu$ l per well]. Using a pipette, $50 \mu \mathrm{l}$ of fluconazole was transferred to the first plate and $100 \mu \mathrm{l}$ of the fungal suspension was added to each well and then incubated for $48 \mathrm{~h}$ at $37^{\circ} \mathrm{C}$. The used concentrations of fluconazole and plant extracts were calculated and expressed in terms of fractional inhibitory concentration index (FICI); equal to the sum of FIC of plant extract and FIC of fluconazole. The FIC was defined as MIC of plant extract and fluconazole in combination divided by MIC of plant extract and fluconazole used alone. The results were considered as a synergistic effect when FICI was less than or equal to 0.5 .

\section{Statistical analysis}

Results were expressed as mean $\pm \mathrm{SD}$ for triplicates. All the data were statistically evaluated with SPSS/19.0 software.

\section{RESULTS AND DISCUSSION}

\section{Qualitative phytochemical analysis}

Preliminary phytochemical analysis of methanol extracts of $G$. glabra, M. chamomilla and E. alba was carried out, and it showed the presence of steroids, saponins, terpenoids, glycosides, tannins and flavonoids in all extracts (table 1). The extract of E. alba showed a negative result in glycosides test.

Table 1: Qualitative phytochemical screening of G. glabra, M. chamomilla and E. alba

\begin{tabular}{llll}
\hline Phytochemicals & G. glabra & M. chamomilla \\
\hline Steroids & + & + & + \\
Terpenoids & + & + & + \\
Saponins & + & + & + \\
Glycosides & + & + & + \\
Tannins & + & + & + \\
Flavonoids & + & + & + \\
Phenols & + & + \\
\hline
\end{tabular}

$+\rightarrow$ Present; $-\rightarrow$ Absent 


\section{Quantitative analysis of phenols and flavonoids}

The total phenol content was tested using Folin-phenol reagent method and showed a significant amount of phenols in all the tested plant. The total phenol and flavonoid contents of methanolic extracts of plants were expressed in Gallic acid (GAE) equivalent/g and Quercetin (QE) equivalent/mg respectively.

Among the tested sample M. chamomilla showed higher phenolic content followed by G. glabra and E. alba. The G. glabra showed high flavonoid content followed by M. chamomilla and E. alba. The phenolic compounds absorb the free radicals by decomposing peroxide $[35,36]$ and hence the phenolic content of the plant is directly proportional to the strong antioxidant activity [37] Many researchers reported that the presence of flavonoids enhances the antimicrobial, antioxidant, anti-inflammatory and vascular activities [38]. Few researchers [39-41] also reported that radical scavenging activities of the plants were linked to the antibacterial properties.

Table 2: Total phenol and flavonoid estimation of G. glabra, M. chamomilla and E. alba

\begin{tabular}{lll}
\hline Methanolic extract & Total phenolic content $(\mathbf{m g ~ G A E} / \mathbf{g})$ & Flavonoid content $(\boldsymbol{\mu g} \mathbf{Q E} / \mathbf{m g})$ \\
\hline M. chamomilla & $1.24 \pm 0.03$ & $231.34 \pm 2.08$ \\
E. alba & $0.64 \pm 0.01$ & $88.00 \pm 1.00$ \\
G. glabra & $0.85 \pm 0.07$ & $356 \pm 3.00$ \\
\hline
\end{tabular}

Values are means of three independent values \pm standard deviations

\section{Antioxidant activity of G. glabra, M. chamomilla and E. alba by DPPH method}

DPPH is a rapid and sensitive method to evaluate the antioxidant capacity of plant extracts. It is based on the decolorization of DPPH in the presence of antioxidants in the tested sample. The color change from purple to yellow shows the strong antioxidant capacity of the sample. According to Shahidi et al. (1992) [42] the antioxidant power is mainly due to the redox nature of phenolic compounds. Also, $\mathrm{Fe}^{3+}-\mathrm{Fe}^{2+}$ transformations would occur in the presence of phenolic compounds. Our results also confirm the above-said statement. As per the results obtained from total phenol, estimation $M$. chamomilla has more phenol content and high radical scavenging activity (85\%) followed by G. glabra (70\%) and E. alba (50\%) [fig. 1].

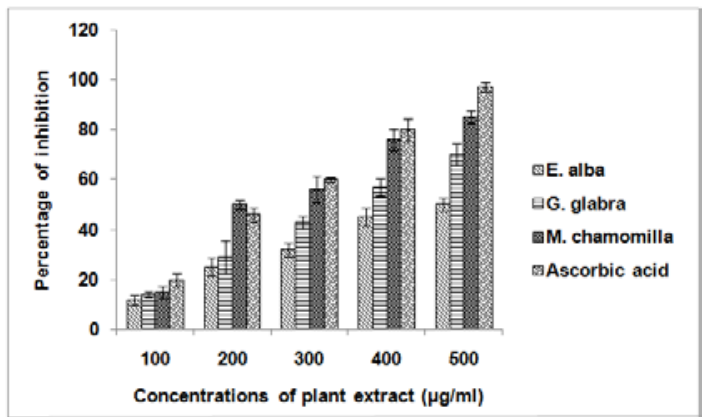

Fig. 1: Antioxidant activity of G. glabra, M. chamomilla and $E$. alba by DPPH assay

\section{ABTS cation free radical scavenging activity}

The free radical scavenging capacity of all the samples was tested using ABTS radical cation decolorization assays [43]. All the extract showed significant scavenging activity with the greatest extent. Among the solvent extract, M. chamomilla (79.58\%) followed by G. glabra (65.03\%) and E. alba (45.67\%) showed $\mathrm{ABTS}^{*+}$ scavenging activity. The standard vitamin E showed $99.6 \%$ scavenging activity against ABTS $^{*+}$.

\section{Antibacterial and antifungal activity of G. glabra, M. chamomilla and E. alba}

The extracts of G. glabra, M. chamomilla, E. alba $(100 \mu \mathrm{g} / \mathrm{ml})$ and chloramphenicol (positive control $30 \mu \mathrm{g} / \mathrm{ml}$ ) showed antibacterial activity against five oral bacterial pathogens except Pseudomonas aeruginosa.

Pseudomonas aeruginosa showed resistant activity against all the extracts tested except positive control which showed $20.4 \mathrm{~mm}$ zone of inhibition. Asan-Ozusaglam and Karakoca (2014) [44] reported that the antibacterial activity of hexane extract of G. glabra root showed $9.25 \mathrm{~mm}$ zone of inhibition only at the concentration of 45 $\mathrm{mg} / \mathrm{ml}$ against $P$. aeruginosa. The lethal or inhibitory effect of the extract is confirmed by determining MIC and MBC values.

The MIC for antibacterial activity ranges from 0.19 to $3.12 \mu \mathrm{g} / \mathrm{ml}$ and $\mathrm{MBC}$ ranges from 6.25 to $50 \mu \mathrm{g} / \mathrm{ml}$. The minimum MIC $(0.19$ $\mu \mathrm{g} / \mathrm{ml}$ ) was observed with E. alba for S. aureus and L. acidophilus. Sultana et al. (2010) [45] concluded that the methanolic root extract of G. glabra showed positive antibacterial activity against all the 11 strains of bacteria except Pseudomonas aeruginosa. This finding is correlating with our results.

Karama et al. (2012) [46] reported that crude herbal mixtures of $10 \%$ Qurecus aegilops, 20\% Salvodora persica, 20\% Cinnamomum zeilanicum, $30 \%$ glycerin oil, $45 \%$ Matricaria chamomilla showed positive zone of inhibition against $S$. mutans $(33.8 \mathrm{~mm})$, S. aureus $(28.7 \mathrm{~mm})$ and $L$ acidophilus ( $40.5 \mathrm{~mm}$ ) whereas in our study methanolic flower extract of M. chamomilla produced $19.8 \mathrm{~mm}$ of zone of inhibition against $S$. mutans, $16.2 \mathrm{~mm}$ for $S$. aureus and $9.8 \mathrm{~mm}$ for L. acidophilus.

The extracts of M. chamomilla and E. alba did not inhibit the growth of Pseudomonas aeruginosa. The similar result was correlated with the previous report of Jehan Bakht et al. (2011) [47]. Marina Sokovic et al. (2010) [48] stated that petroleum ether, dichloromethane, methanol and water extracts of E. alba leaves did not inhibit the growth of $P$. aeruginosa even at higher concentrations. The essential oils from M. chamomilla did not showed any antibacterial effect against $P$. aeruginosa and Proteus mirabilis.

According to Natalia Martins et al. (2016) [49], C. tropicalis were more susceptible to the phenolic extracts of licorice followed by C. glabrata, $C$. parapsilosis and $C$. albicans. Our results were different from this may be due to the different solvent used for the extraction process.

Table 3: Antibacterial activities of G. glabra, M. chamomilla and E. alba

\begin{tabular}{|c|c|c|c|c|}
\hline Plants & G. glabra & M. chamomilla & E. alba & Chloramphenicol \\
\hline \multicolumn{5}{|c|}{ Microorganism } \\
\hline S. aureus & $15.03 \pm 0.25$ & $16.2 \pm 0.3$ & $21.6 \pm 0.5$ & $24.9 \pm 0.15$ \\
\hline S. mitis & $14.2 \pm 0.2$ & $16.7 \pm 0.7$ & $18.8 \pm 0.7$ & $15.83 \pm 0.2$ \\
\hline S. oralis & $12.66 \pm 2.5$ & $16.03 \pm 0.1$ & $14.66 \pm 0.5$ & $19.86 \pm 0.8$ \\
\hline S. mutans & $21 \pm 0.05$ & $19.8 \pm 0.5$ & $16.9 \pm 0.1$ & $22.3 \pm 0.5$ \\
\hline L. acidophilus & $11.66 \pm 0.5$ & $9.8 \pm 0.2$ & $10.7 \pm 0.68$ & $9.8 \pm 0.1$ \\
\hline P. aeruginosa & - & - & - & $20.4 \pm 0.8$ \\
\hline
\end{tabular}

Values are mean inhibition zone $(\mathrm{mm}) \pm S D$ of triplicates, Plant extracts $-100 \mu \mathrm{g} / \mathrm{ml}$, Chloramphenicol $-30 \mu \mathrm{g} / \mathrm{ml}$, [-= no inhibition] 
Table 4: Antifungal activity of G. glabra, M. chamomilla and E. alba

\begin{tabular}{llll}
\hline Fungi & C.parapsilosis & C. krusei & C. tropicalis \\
\hline Plant extracts & & C. albicans & - \\
M. glabra chamomilla & $10.66 \pm 1.15$ & - & - \\
E. alba & - & - & - \\
Fluconazole & - & $24 \pm 107$ & $13.66 \pm 3.5$ \\
\hline
\end{tabular}

Values are mean inhibition zone $(\mathrm{mm}) \pm$ SD of three replicates, Plant extracts- $250 \mu \mathrm{g} / \mathrm{ml}$, Fluconazole- $20 \mathrm{mg} / \mathrm{ml}$, [-= no inhibition]

Table 5: MIC values of G. glabra, M. chamomilla and E. alba against oral bacteria

\begin{tabular}{|c|c|c|c|c|}
\hline Plant (in $\mu \mathrm{g} / \mathrm{ml}$ ) & G. glabra & M. chamomilla & E. alba & Chloramphenicol \\
\hline \multicolumn{5}{|l|}{ Bacteria } \\
\hline S. aureus & 3.12 & 3.12 & 0.19 & - \\
\hline S. mitis & 0.78 & 3.12 & 3.12 & 0.09 \\
\hline S. oralis & 3.12 & 3.12 & 0.78 & - \\
\hline S. mutans & 0.78 & 0.39 & 0.39 & - \\
\hline L. acidophilus & 3.12 & 0.39 & 0.19 & - \\
\hline P. aeruginosa & - & - & - & \\
\hline
\end{tabular}

Values are mean of triplicates

Table 6: MIC values of G. glabra, M. chamomilla and E. alba against oral fungi

\begin{tabular}{llll}
\hline Fungi & C. parapsilosis & C. $k r u s e i$ & C. tropicalis \\
\hline Plant extracts $(\mathrm{in} \mu \mathrm{g} / \mathrm{ml})$ & & C. albicans & - \\
\hline G. glabra & $62.5 \mathrm{mg} / \mathrm{ml}$ & - & - \\
M. chamomilla & - & - & - \\
E. alba & - & $0.25 \mu \mathrm{g} / \mathrm{ml}$ & - \\
Fluconazole & $24 \mu \mathrm{g} / \mathrm{ml}$ & $0.5 \mu \mathrm{g} / \mathrm{ml}$ & $3 \mu \mathrm{g} / \mathrm{ml}$ \\
\hline
\end{tabular}

Values are mean of triplicates

\section{Antiadherence activity}

The antiadherence activity of methanol extracts of G. glabra, M. chamomilla and E. alba was carried out. All the methanolic plant extracts showed reduced percentage of adherence whereas positive control (Chloramphenicol) showed a higher percentage of adherence. This clearly indicates that the plant extracts can prevent bacterial colony formation in the oral cavity which leads prevent the oral infections.

Many medicinal plant extracts were investigated to prevent the oral biofilm formation. The initial stage of biofilm formation was also inhibited by cranberry juice thereby also inhibiting the dental plaque formation [50]. Ooshima et al. (2000) [51] also reported that the growth rate of $S$. mutans was reduced by cacao bean husk by 69 72 percentages.

\section{Sorbitol assay}

Sorbitol is an osmoprotectant which is used to stabilize fungal cell wall. The test was performed with plant extracts and fungi in presence and absence of sorbitol $(0.8 \mathrm{M})$. The MIC in presence and absence of sorbitol $(62.5 \mathrm{mg} / \mathrm{ml})$ would remain same which indicates that the extract of G. glabra would not target the cell wall synthesis or cell wall assembly to inhibit the fungi.

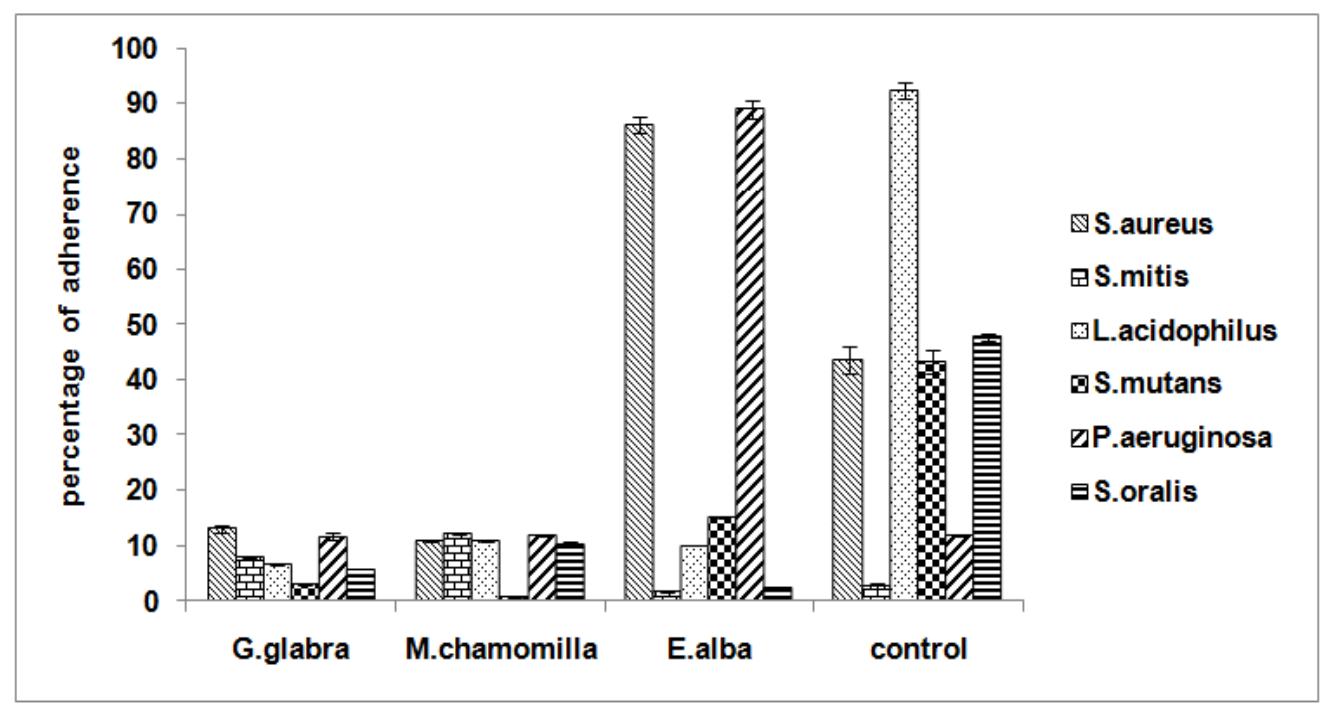

Fig. 2: Antiadherence activity of G. glabra, M. chamomilla and E. alba 


\section{Mechanism of antifungal activity}

\section{Scanning electron microscopy}

Scanning electron microscopy was performed to find out the morphological changes in C. parapsilosis after exposure to G. glabra methanolic extract at the MIC concentration $(62.5 \mathrm{mg} / \mathrm{ml})$ for $48 \mathrm{~h}$. Untreated and treated samples were taken for comparison. Untreated cells shows spherical cells with smooth surface whereas treated cells shows complete morphological changes with the elongated surface with rough appearance and most of the cells were completely deteriorated by the release of cellular constituents which indicate the cytoplasmic damage of fungi and has to further confirmed by transmission electron microscopy.

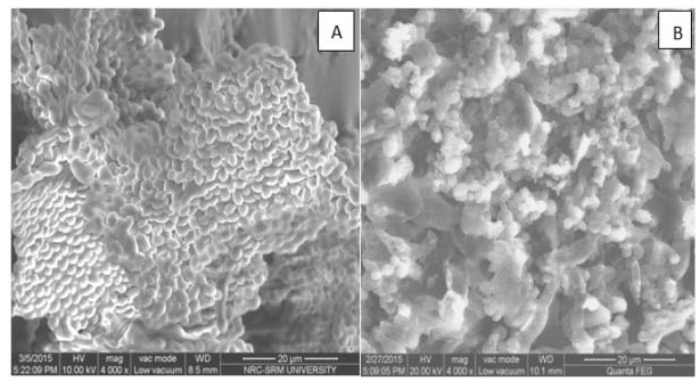

Fig. 3: SEM Micrographs of untreated (A) and treated (B) samples

\section{Transmission electron microscopy}

Based on the results obtained from SEM analysis, the fungi $C$. parapsilosis were exposed to the methanolic extract of G. glabra at the MIC concentration $(62.5 \mathrm{mg} / \mathrm{ml})$.

The untreated samples has a smooth and spherical surfaces whereas treated samples shows slight morphological changes (A and B) in the beginning followed by cell elongation (C) and oozing of cellular constituents (D) followed by cytoplasmic membrane and cell wall damage (E) and finally complete damage of the cell $(F)$.

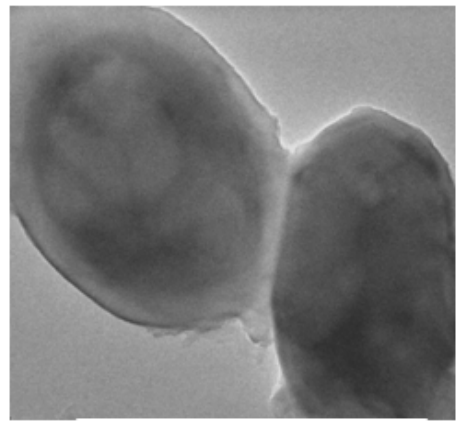

Untreated sample
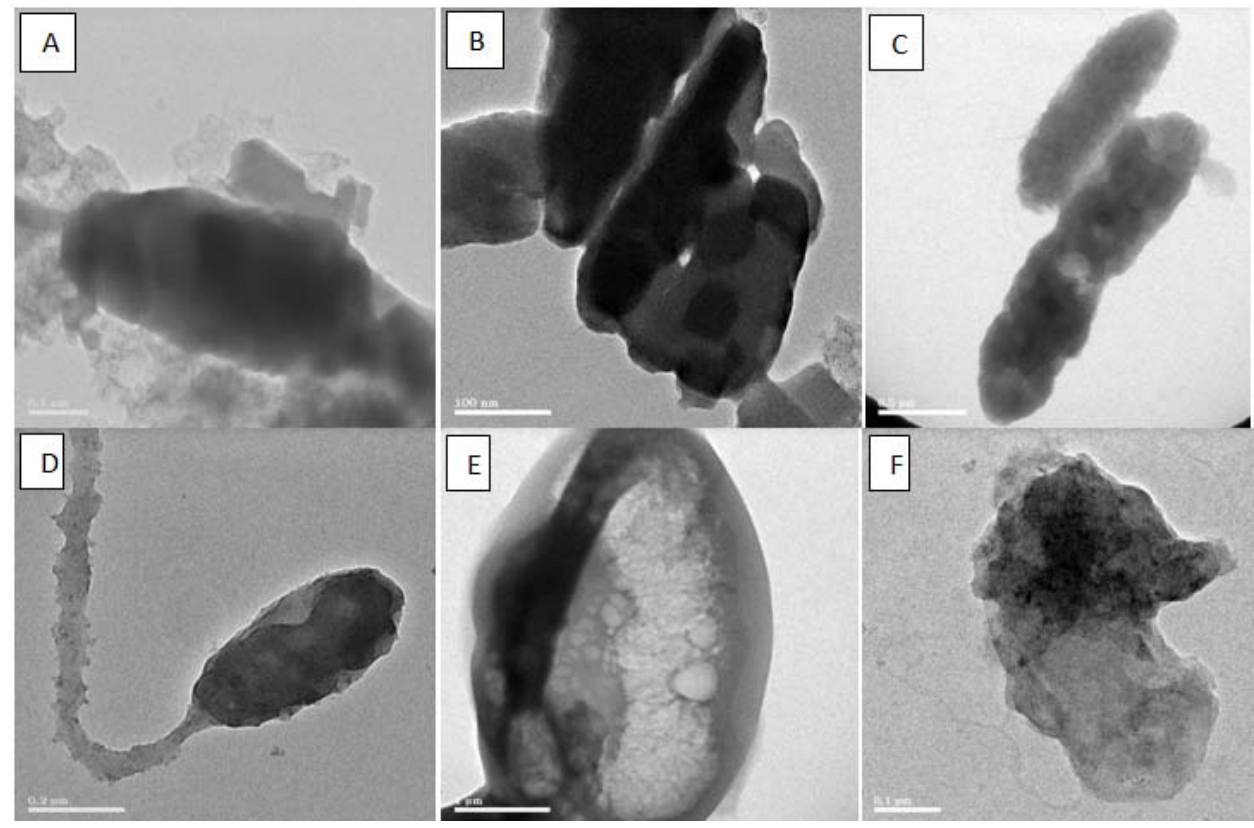

Fig. 4: TEM analysis of Candida parapsilosis with untreated and treated sample

\section{Flow cytometry}

Propidium iodide (PI) is a nucleic acid binding fluorescent probe commonly employed to evaluate the effect of drugs on cell membranes. Cells with severe membrane lesion leading to inherent loss of viability will internalize propidium iodide, resulting in an increase in fluorescence. The PI penetration in $C$. parapsilosis cells treated with various concentrations of test compounds and positive control (Fluconazole) is shown in the following graph. Our results showed G. glabra being most effective in damaging the cell membrane of Candida cells in the treatment of one hour. Substantial morphological changes were observed on scattergram of cells upon treatment with test agents. The production of membrane lesion by test agents was increasing with increase in concentration. Further confirmation on membrane damages produced by these compounds was done by performing the flow cytometry of treated fungal cells using propidium iodide as a fluorescent marker.
The above result clearly mentioned that the cell counts decreased in a dose-dependent manner and shows maximum cell count damage at the MIC concentration (M1) whereas cell count damage is high in the untreated sample (M2).

\section{Synergism}

The combination between the plant extract and antimicrobial drugs has been referred as a strategy for combating various microbial developments due to the production of the synergistic effect.

The synergistic effect of plant extract G. glabra with fluconazole was studied against Candida parapsilosis. A synergistic effect was given by FICI which is given by MIC of fluconazole and plant extract in combination divided by MIC of fluconazole and plant extract used alone. MIC of plant extract and fluconazole is equal to FIC of plant extract and fluconazole respectively. 


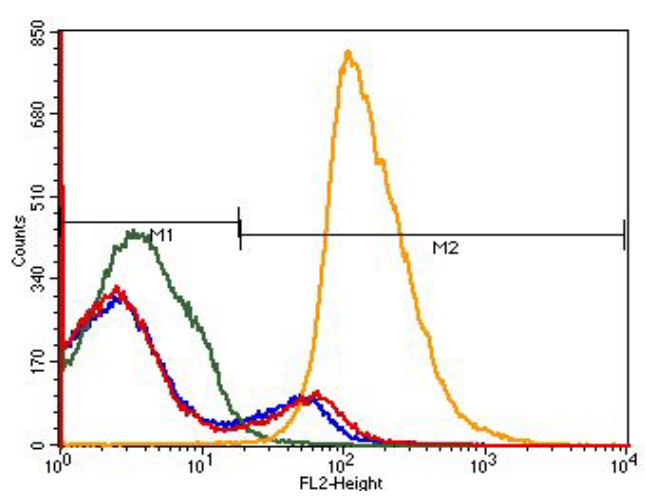

Fig. 5: Flow cytometric analysis of G. glabra

Synergism is defined as FIC index of 0.5 or less, if FICI is more than 0.5 and between 4 then addictively and FICI more than 4 then antagonistic effect. Thus the FICI of 0.5 of our plant extract with $C$. parapsilosis showed that our plant extract has potential synergistic effect with fluconazole. Thus Glycyrrhiza glabra has potential as a therapeutic option against $C$. parapsilosis cells due to its fungicidal ability and synergistic effect with fluconazole.

\section{CONCLUSION}

The results indicated that the methanol extracts of G. glabra, M. chamomilla and E. alba showed a significant antibacterial, antifungal and antioxidant activities. Therefore further studies are required to identify the active compounds of these plants and to develop oral care products for the herbal remedy for the oral infections.

\section{ACKNOWLEDGEMENT}

The Authors greatly express their thanks to Prof. C. Muthamizchelvan, Director, Engineering and Technology, Dr. M. Vairamani, Dean, School of Bioengineering, Prof. Srinivasan Thyagarajan, HOD, Department of Biotechnology, SRM University for providing facilities and their cordial support.

\section{CONFLICT OF INTERESTS}

We have no conflict of interest to declare

\section{REFERENCES}

1. Parsek M, Singh PK. Bacterial biofilms: an emerging link to disease pathogenesis. Annu Rev Microbiol 2003;57:677-770.

2. Wu CD, Wei GX. Tea as a functional food for oral health. Nutrition 2002;18:443-4.

3. Hardie JM. Oral microbiology: current concepts in the microbiology of dental caries and periodontal disease. Br Dent J 1992;172:271-81

4. Ooshima T, Osaka Y, Sasaki H, Osawa K, Yasuda H, Matsumura $\mathrm{M}$, et al. Caries inhibitory activity of cacao bean husk extract in vitro and animal experiments. Arch Oral Biol 2000;45:639-45.

5. Beaglehole R, Benzian, Crail HJ. The Oral Health Atlas. Mapping a neglected global health issue. FDI. World Dental Federation. Geneve; 2009.

6. Rolston KV, Jones RN, Coyle EA, Prince RA. Emergence of quinolone resistant Escherichia coli at a cancer center [abstract] $45^{\text {th }}$ Annual Meeting of the Infectious Diseases Society of America (IDSA), San Diego, CA; 2007. p. 506.

7. Akharaiyi FC, Boboye B, Adetuyi FC. Antibacterial, phytochemical and antioxidant activities of the leaf extracts of Giricidia sepium and Spathodea campanulata. World Appl Sci J 2012;16:523-30.

8. Knoll-Kohler E, Stiebel J. Amine fluoride gel affects the viability and the generation of superoxide anions in human polymorphonuclear leukocytes: an in vitro study. Eur J Oral Sci 2002;110:296-301.

9. Neumegen RA, Fernández-Alba AR, Chisti Y. Toxicities of triclosan, phenol, and copper sulfate in activated sludge. Environ Toxicol 2005;20:160-4.
10. Hanrahan, Clare, Frey, Rebecca. "Chamomile". Gale Encyclopedia of Alternative Medicine; 2005.

11. Tewari SN, Wilson AK. Deglycyrrhizinated liquorice in duodenal ulcer. Practitioner 1973;210:820-3.

12. Steinberg D, Feldman M, Ofek I, Weiss EI. Effect of a highmolecular-weight component of cranberry on constituents of dental biofilm. J Antimicrob Chemother 2004;54:86-9.

13. Yamanaka R, Kimizuka, Kato T, Okuda K. Inhibitory effects of cranberry juice on attachment of oral streptococci and biofilm formation. Oral Microbiol Immunol 2004;19:150-4.

14. Limsong J, Benjavongkulchai E, Kuvatanasuchati J. Inhibitory effect of some herbal extracts on adherence of Streptococcus mutans. J Ethnopharmacol 2004;92:281-9.

15. Nagata H, Innagaki Y, Yamamoto Y, Maeda K, Kataoka K, Osawa K. Inhibitory effects of macro carpals on the biological activity of Porphyromonas gingivalis and other peridontopathic bacteria. Oral Microbiol Immunol 2006;21:159-63.

16. Labrecque J, Bodet C, Chandad F, Grenier D. Effects of a highmolecular-weight cranberry fraction on growth, biofilm formation and adherence of Porphyromonas gingivalis. J Antimicrob Chemother 2006;58:439-43.

17. Yatsuda R, Rosalen PL, Cury JA. Effects of Mikania genus plants on growth and cell adherence of mutans Streptococci. J Ethnopharmacol 2005;97:183-9.

18. Halli Well B, Gutteridge JM. Oxygen toxicity, oxygen radicals, transition metals, and diseases. Biochem J 1984;219:1-14.

19. Maxwell SR. Prospect for the use of antioxidant therapies. Drugs 1995;49:45-361.

20. Bouftira Ibtissem, Chedly Abdelly, Souad S far. Antioxidant and antibacterial properties of Mesembryanthemum crystallinum and Carpobrotus edulis extracts. Adv Chem Eng Sci 2012;2:359-65.

21. Harborne JB. Phytochemical methods. Chapman and Hall Ltd, London; 1973. p. 49-188.

22. Sofowora A. Screening plants for bioactive agents. In: Medicinal plants and traditional medicinal in Africa. 2nd ed. Spectrum Books Ltd: Sunshine House; 1993.

23. Trease GE, Evans WC. Pharmacognosy. $11^{\text {th }}$ ed. Bailliere: Tindall London; 1989.

24. Singleton VL, Rossi JA. Colorimetry of total phenolics with phosphomolybdic-phosphotungstic acid reagents. Am J Enol Vitic 1965;16:144-58.

25. Lin J, Tang C. Determination of total phenolic and flavonoid contents in selected fruits and vegetables, as well as their stimulatory effects on mouse splenocyte proliferation. Food Chem 2007;101:140-7.

26. Om Sharma P, Tej Bhat K. DPPH antioxidant assay revisited. Food Chem 2009;113:1202-5.

27. Re R, Pellegrini N, Proteggente A, Pannala A, Yang M, RiceEvans C. Antioxidant activity applying an improved ABTS radical cation decolorization assay. Free Radical Biol Med 1999;26:1231-7.

28. Bauer AW, Kirby WMW, Sherris JC, Turck M. Antibiotic susceptibility testing by a standardized single disc method. AM J Clin Pathol 1966;44:493-6.

29. McFarland J. Standardization of bacterial culture for disc diffusion assay. JAMA J Am Med Assoc 1987;49:1176-8.

30. Baron EJ, Finegold SM. Bailey and Scotts 'Diagnostic Microbiology'. 8th ed. USA: Mosby; 1990. p. 176-82.

31. Barira Islam, Shahper Khan N, Irfanul Haque, Alam M, Mushfiq $\mathrm{M}$, Asad Khan. Novel anti-adherence activity of mulberry leaves Inhibition of Streptococcus mutans biofilm by 1deoxynojirimycin isolated from Morus alba. J Antimicrob Chemother 2008;62:751-7.

32. Frost DJ, Brandt KD, Cugier D, Goldman R. A whole-cell Candida albicans assay for the detection towards fungal cell wall synthesis and assembly. J Antibiot 1995;48:306-10.

33. Figueras MJ, Guarro J. X-ray microanalysis of black piedra. Antonie Van Leeuwenhoek 1997;72:275-81.

34. Jaeyong cho, Hyemin Choi, Juneyoung Lee, Mi-Sun Kim, HoYong Sohn, Dong Gun Lee. The antifungal activity and membrane-disruptive action of dioscin extracted from Dioscorea nipponica. Biochim Biophys Acta Biomembr 2013;1828:1153-8. 
35. Yingming $\mathrm{P}$, Hengshan $\mathrm{W}$, Min L. Antioxidant activities of several Chinese medicinal herbs. Food Chem 2004;88:347-50.

36. Louli V, Ragoussis N, Maglulas K. Recovery of phenolic antioxidants from wine industry by-products. Bioresour Technol 2004;92:201-8.

37. Oktay M, Gulcin I, Kufrevioglu OI. Determination of in vitro antioxidant activity of fennel (Foeniculum vulgare) seed extracts. Lebensm Wiss Technol 2003;36:263-71.

38. Diksa Devi $\mathrm{T}$, Deena Ramdul B, Daneshwar P. In vitro bioactivity and phytochemical screening of selected spices used in mauritian foods. Asian Pac J Trop Dis 2013;3:253-61.

39. Akroum S, Dalila S, Kirrich L. Antimicrobial, antioxidant, cytotoxic activities and phytochemical screening of some Algerian plants. Eur J Sci Res 2009;31:289-95.

40. De N, Ifeoma E. Antibacterial effects of the components of the bark extract of Neem (Azadirachta indica). Juss Tech-Dev 2000;8:23-8.

41. Ruiz-Teran F, Medrano Martinez A, Navarro Ocana A Antioxidant and free radical scavenging activities of plant extracts used in traditional medicine in Mexico. Afr J Biotechnol 2008;7:1886-93.

42. Shahidi F, Janitha PK, Wanasundara PD. Phenolic antioxidants. Crit Rev Food Sci Nutr 1992;32:67-103.

43. Roberta R, Nicoletta P, Anna Proteggente, Ananth P, Min yang, Catherine Rice-Evans. Antioxidant activity is applying an improved ABTS radical cation decolorization assays. Free Radicals Biol Med 1999;9:1231-7.

44. Asan-Ozusaglam M, Karakoca K. Evaluation of biological activity and antioxidant capacity of Turkish licorice root extracts. Rom Biotechnol Lett 2014;19:8994-9005.
45. Sultana S, Haque A, Hamid K, Urmi KF, Roy S. Antimicrobial cytotoxic and antioxidant activity of methanolic extract of $G$ glabra. Agric Biol J North Am 2010;1:957-60.

46. Karama T, Al-Taee, Sadad S, Al-Ani, Khadijak, Al-Dulaiml, et al. Antibacterial activity of crude herbal mixture (Oak bark, Miswak, Cinnamon, Mint, Clove, Common chamomile, Glycerin oil) on oral pathogenic bacterias. Al-Anb Med J 2012;10:78-85.

47. Jehan Bakht, Ajmad Islam, Mohammad Shafi. Antimicrobial potentials of E. alba by well diffusion method. Pak J Bot 2011;43:169-74.

48. Marina Sokovic, Jasmina Glamoclija, Petar D Marin, Dejan Brkic, Leo Van Griiensven JLD. Antibacterial effects of the essential oils of commonly consumed medicinal herbs using an in vitro model. Molecules 2010;15:7532-46.

49. Natalia Martins, Isabel CFR, Ferreira, Mariana Henriques, Sonia Silva. In vitro anti-candidal activity of Glycyrrhiza glabra L. Ind Crops Prod 2016;83:81-5.

50. Enzo A Palombo. Traditional medicinal plant extracts and natural products with activity against oral bacteria: potential application in the prevention and treatment of oral diseases. J Evidence-Based Complementary Altern Med 2011;1-15. Doi.org/10.1093/ecam/nep067.

51. Ooshima T, Osaka Y, Sasaki H. Caries inhibitory activity of cacao bean husk extract in in vitro and animal experiments. Arch Oral Biol 2000;45:639-45.

\section{How to cite this article}

- Lavanya J, Periyar Selvam S, Jeevitha Priya M, Preethi Jacintha, Aradana M. Antioxidant and antimicrobial activity of selected medicinal plants against oral human pathogens. Int J Pharm Pharm Sci 2016;8(9):71-78. 